\title{
O PRZESTRZENNYM ZRÓŻNICOWANIU STRUKTUR WIEKU LUDNOŚCI W POLSCE, 1991-2011
}

\section{Wprowadzenie}

W ocenie starości demograficznej wykorzystuje się wiele miar. Zasadniczo miary te można podzielić na trzy grupy. Do pierwszej należą te, które przedstawiają relację między liczbą (lub odsetkiem) osób będących w określonym wieku. Są to m.in.: indeks starości ${ }^{1}$, alternatywny indeks starości ${ }^{2}$, wskaźnik starości ${ }^{3}$, współczynnik obciążenia demograficznego ${ }^{4}$, współczynnik obciążenia osobami młodymi ${ }^{5}$, współczynnik obciążeń osobami starszymi ${ }^{6}$, współczynnik wsparcia ${ }^{7}$, współczynnik wsparcia dla osób najstarszych ${ }^{8}$. Korzystając z relacji między poszczególnymi grupami wieku, zaproponowano różne skale oceny starości demograficznej. Do najczęściej przytaczanych należy podział zaproponowany przez R. Rosseta ${ }^{9}$, gdzie przez młodość demograficzną rozumiemy sytuację, w której wskaźnik starości wynosi mniej niż 8\%. Kolejny poziom, nazwany wczesną fazą przejścia między młodością a starością

1 Indeks starości liczony jako iloraz liczby osób w wieku 60 lat i więcej na 100 osób w wieku poniżej 15 roku życia.

2 Alternatywny indeks starości wyznacza się podobnie jak indeks starości, ale starszym grupom wieku przyporządkowuje się wagi w ten sposób, że im większa odległość od ustalonego wieku krytycznego, tym wyższa ich wartość.

3 Wskaźnik starości wyraża stosunek liczby osób w wieku 60 (lub 65 lat i więcej) do ogólnej liczby ludności.

4 Współczynnik obciążenia demograficznego określa stosunek liczby osób w wieku nieprodukcyjnym na 100 osób w wieku produkcyjnym.

5 Współczynnik obciążenia osobami młodymi jest to relacja między osobami w wieku 0-14 lat na 100 osób w wieku 15-64 lata.

6 Współczynnik obciążeń osobami starszymi liczony jako iloraz liczby osób w wieku 65 lat lub więcej na 100 osób w wieku 15-64 lata.

7 Współczynnik wsparcia analizuje liczbę osób w wieku 15-64 lata przypadającą na 100 osób w wieku 65 lat i więcej.

8 Współczynnik wsparcia dla osób najstarszych liczony jako liczba osób w wieku 85 lat i więcej na 100 osób w wieku 50-64 lata.

9 E. Rosset, Proces starzenia się ludności. Studium demograficzne, PWG, Warszawa 1959; E. Rosset, Ludzie starzy. Studium demograficzne, PWE, Warszawa 1967. 
demograficzną, określa wartość tej miary na poziomie 8-10\%. O późnej fazie przejścia między młodością a starością mówimy wtedy, gdy odsetek osób w wieku powyżej 60 lat zawiera się w granicach 10-12\%. Starość demograficzna następuje wtedy, gdy miara ta przyjmuje wartości wyższe niż $12 \%$. Według propozycji ONZ ${ }^{10}$ przez młodą populację rozumiemy stan, w którym odsetek osób w wieku 65 lat i więcej jest niższy niż 4\%. O populacji dojrzałej mówimy wtedy, kiedy udział ten wynosi od $4 \%$ do $7 \%$, a o starej, gdy przekroczył 7\%. Wydaje się, że przedstawione propozycje oceny starości demograficznej nie są zbyt adekwatne w odniesieniu do dnia dzisiejszego. W latach 60. przeciętne dalsze trwanie życia w chwili narodzin było o ponad 10 lat krótsze aniżeli w pierwszej dekadzie XXI w. Należy zatem wiek określający dolną granicę starości demograficznej podnieść o ten przyrost lub wartość do niego zbliżoną. W literaturze przedmiotu często granicę tę określa również moment zakończenia aktywności zawodowej ludności. W drugiej z proponowanych ocen stopnia zaawansowania starości demograficznej wykorzystuje się informacje o przeciętnym dalszym trwaniu życia lub syntetycznych miarach statystycznych opisujących rozkład liczby ludności według wieku. W pierwszym z wymienionych przypadków granica wieku starości demograficznej określona została przez różnicę między przeciętnym dalszym trwaniem życia w chwili narodzin a pewną arbitralnie ustaloną liczbą lat, która określa już okres życia w starości. Próg starości demograficznej może określać dolna granica wieku starczego wynosząca 15 lat $^{11}$. Dla tak wyznaczonych grup wieku zaproponowano również wiele wskaźników, których konstrukcja opiera się na tych samych zasadach co w przypadku relacji między liczbą osób przynależnych do określonych grup wieku, ale w tym przypadku granice tych grup wyznacza liczba lat pozostała do przeżycia oraz liczba lat już przeżytych ${ }^{12}$. Wśród miar uwzględniających ten sposób oceny starości demograficznej można wymienić m.in. potencjalny indeks starości czy potencjalny współczynnik obciążenia osobami starszymi. Natomiast wśród syntetycznych miar statystycznych pozwalających dokonać oceny rozkładu struktury ludności według wieku można m.in. wymienić medianę ${ }^{13}$, decyle ${ }^{14}$ czy kwartyle ${ }^{15}$. Również i w tym przypadku w ocenie stopnia zaawansowania starości demograficznej

10 World Population Prospects: The 2004 Revision, UN Department of Economic and Social FFAIRS Population Division, New York 2005.

11 W. Sanderson, S. Scherbov, Average remaining lifetimes can increase as human populations age, "Nature” 2005, No. 435, s. 811-813; W. Sanderson, S. Scherbov, A new perspective on population ageing, „Demographic Research" 2007, No. 16(2), s. 27-58.

12 A. Abramowska-Kmon, O nowych miarach zaawansowania procesu starzenia się ludności, „Studia Demograficzne” 2011, nr 1(159), s. 3-33.

13 L. Kosiński, Geografia ludności, PWN, Warszawa 1967.

14 J.I. Clarke, Population geography, Pergamon Press, Oxford 1965.

15 J. Kowaleski, Przestrzenne zróżnicowanie starzenia się ludności Polski. Przyczyny - Etapy - Następstwa, Wydawnictwo UŁ, Łódź 2011. 
wykorzystano relację między tak wyznaczonymi podgrupami. Oceny zaawansowania starzenia się ludności można dokonać przez ocenę odległości między ustalonym progiem starości a średnim wiekiem osób starszych w populacji (relatywna luka starości ${ }^{16}$. Im wyższa wartość tej miary, tym starsza populacja. Jeżeli miara ta zostanie dodatkowo skorygowana przez udział osób w wieku starszym, to uzyskamy nową jej odmianę, nazywaną wskaźnikiem starości z ustalonym wiekiem starości.

Zaletą przedstawionych miar jest ich prostota w liczeniu, a wadą to, że nie biorą pod uwagę całej struktury ludności według wieku. Uwaga ta ma szczególne znaczenie w przypadku występowania niżów i wyżów demograficznych. Dlatego też zaproponowano alternatywne podejście, które niestety rzadko jest stosowane, a które do oceny stopnia zaawansowania stopnia starości demograficznej wykorzystuje informacje o całej strukturze ludności. Wśród stosowanych miar można wymienić m.in. współczynnik koncentracji ${ }^{17}$, syntetyczny wskaźnik struktury wieku ${ }^{18}$. Ta ostatnia miara liczona jest jako suma iloczynów udziałów ludności w poszczególnych rocznikach oraz przyporządkowanych tym rocznikom pewnych wag. Wartość tych wag rośnie w postępie arytmetycznym (bądź geometrycznym) wraz z wiekiem. Im wyższa wartość tej miary, tym wyższy stopień zaawansowania starości demograficznej. Można wykorzystać łącznie informacje o średniej wieku oraz o postaci rozkładu ${ }^{19}$. Jeżeli wartość tej miary równa się średniej wieku, to przyjmuje się, że populacja jest młoda. Im zaś wartości są wyższe, tym wyższy stopień zaawansowania starości demograficznej. Można wyznaczyć też indeks niepodobieństwa ${ }^{20}$, który stanowi połowę sumy absolutnych różnic pomiędzy udziałami procentowymi populacji standardowej i porównywanej w poszczególnych grupach wieku. Jako populację standardową przyjmuje się rozkład ludność według wieku odnotowany w jednostce nadrzędnej, w stosunku do której dokonuje się pomiaru. W innej propozycji ${ }^{21}$ wykorzystano metodę podobieństwa struktur. Za populację standardową przyjęto populację regresywną (odwrócona piramida wieku), a następnie dokonano oceny, na ile rzeczywista struktura wieku różni się od tej hipotetycznej. W przypadku oceny dynamiki procesu

16 S.M. Kot, J. Kurkiewicz, The New measures of the population ageing, „Studia Demograficzne” 2004, nr 2/146, s. 17-29.

17 H. d Albis, F. Collard, Age groups and the measure of population aging, „Demographic Research” 2013, No. 29, s. 617-640.

${ }_{18}$ S. Kurek, Typologia starzenia się ludności Polski w ujęciu przestrzennym, „Prace Monograficzne” nr 497, Wydawnictwo Akademii Pedagogicznej w Krakowie, Kraków 2008.

19 M. Cieślak, Pomiar procesu starzenia się ludności, „Studia Demograficzne” 2004, nr 2/146, s. 3-16.

20 D.T. Rowland, Population momentum as a measure of aging, ,European Journal of Population” 1996, No. 12 , s. 41-61.

${ }^{21}$ M. Podogrodzka, Przestrzenne zróżnicowanie ludności według wieku w Polsce w 1991-2010, w: Polityka społeczna wobec przemian demograficznych, red. A. Rączaszek, W. Koczur, „Studia Ekonomiczne” nr 167, Wydawnictwo UE w Katowicach, Katowice 2014, s. 62-76. 
starzenia się ludności wykorzystuje się przede wszystkim informacje o relacjach między punktowymi wartościami przedstawionych wyżej wskaźników starości demograficznej ${ }^{22}$. Rzadziej wyznacza się iloraz między średnim rocznym tempem wzrostu liczby ludności w wieku starszym do średniego rocznego tempa wzrostu ludności ogółem ${ }^{23}$ czy agregatowy indeks struktury ludności, liczony jako iloraz umieralności faktycznej i standaryzowanej w badanej zbiorowości ${ }^{24}$. W pracy E. Frątczak ${ }^{25}$ można znaleźć przegląd modeli demograficznych do badania starzenia się ludności w czasie, ze szczególnym uwzględnieniem modelu ludności ustabilizowanej.

W polskiej literaturze przedmiotu można znaleźć wiele prac poświęconych zagadnieniom oceny natężenia oraz dynamiki starości demograficznej w ujęciu przestrzennym. Wśród prac powstałych w ostatnich 20 latach można wymienić m.in. opracowania Z. Długosza, S. Kurka, A. Potrykowskiej, J. Kowaleskiego, M. Podogrodzkiej ${ }^{26}$. Jednocześnie w pracach tych do opisu natężenia stopnia zaawansowania starości demograficznej wykorzystywano przede wszystkim wskaźniki struktury, a do opisu jego zmian w czasie jedynie proste indeksy dynamiki. Analizy te nie były też prowadzone w podziale według płci. Wydaje się, że analiza procesu starzenia się kobiet i mężczyzn jest szczególnie ważna w przypadku prognoz środków wydatkowanych na opiekę społeczną czy zdrowotną, ponieważ stan zdrowia kobiet w starszych grupach wieku jest znacznie gorszy aniżeli mężczyzn ${ }^{27}$.

Celem badania jest opis przestrzennego zróżnicowania stopnia zaawansowania starości demograficznej przy wykorzystaniu dwóch miar oceny struktury wieku oraz

22 Z. Długosz, Stan i dynamika starzenia się ludności Polski, „Czasopismo Geograficzne” 1997, nr 68(2), s. 227-232; Z. Długosz, Próba określenia zmian starości demograficznej Polski w ujęciu przestrzennym, „Wiadomości Statystyczne" 1998, nr 3, s. 15-25; S. Kurek, Typologia starzenia się..., op.cit.; J. Kowaleski, Przestrzenne zróżnicowanie..., op.cit.

${ }^{23}$ W. Kondrat, Zmiany w strukturze ludności według płci i wieku w latach 1950, 1960, 1970, „Studia i Prace Statystyczne" 1972, $\mathrm{nr} 40$.

${ }^{24}$ I.G. Wieniecki, Starzenie się ludności i metody statystyczne jego pomiaru, w: Metody statystyczne $w$ demografii, PWN, Warszawa 1981, s. 76-90.

25 E. Frątczak, Proces starzenia się ludności Polski, „Studia Demograficzne” 2002, nr 2(142), s. 3-28.

26 Z. Długosz, Stan i dynamika..., op.cit.; S. Kurek, The spatial distribution of population ageing in Poland in the years 1988-2001, „Bulletin of Geography” 2004, No. 2, s. 65-76; S. Kurek, Typologia starzenia się..., op.cit.; A. Potrykowska, Przestrzenne zróżnicowanie procesu starzenia się ludności i migracji osób w starszym wieku w Polsce, „Przegląd Geograficzny” 2003, nr 1, s. 41-59; J. Kowaleski, Przestrzenne zróżnicowanie..., op.cit.; M. Podogrodzka, op.cit.

27 P. Błędowski, Samodzielność osób starszych jako zadanie polityki społecznej, „Gerontologia Polska” 1998, nr 6, s. 3-4; P. Błędowski, Lokalna polityka społeczna wobec ludzi starszych, Oficyna Wydawnicza SGH, Warszawa 2002; B. Urbaniak, Społeczno-ekonomiczne skutki starzenia się społeczeństw, w: Przeobrażenia demograficzne kraju i ich konsekwencje dla polityki społecznej, red. L. Frąckiewicz, Wydawnictwo AE w Katowicach, Katowice 1998; Ludzie starzy w polskim społeczeństwie w pierwszych dekadach XXI wieku, red. J.T. Kowaleski, Wydawnictwo UŁ, Łódź 2006; Nasze starzejące się społeczeństwo. Nadzieje i zagrożenia, red. J.T. Kowaleski, P. Szukalski, Wydawnictwo UŁ, Łódź 2004; Starość i starzenie się jako doświadczenie jednostek i zbiorowości ludzkich, red. J.T. Kowaleski, P. Szukalski, Wydawnictwo UŁ, Łódź 2006. 
zbadanie, na ile uzyskane wyniki różnią się między sobą. Rozważania prowadzone są dla lat 1991, 2001 i 2011 według województw oraz odrębnie dla populacji kobiet i mężczyzn. Opis ten pozwoli na weryfikację następujących hipotez badawczych: 1) województwa o podobnym stopniu zaawansowania starości demograficznej tworzą zwarte przestrzennie obszary (wspólna co najmniej jedna granica); 2) stale w czasie wschodnia część kraju odznacza się wyższym stopniem zaawansowania starości demograficznej aniżeli jej część zachodnia; 3) delimitacja obszarów podobnych nie różni się w populacji kobiet i mężczyzn; 4) różne miary oceny starości demograficznej prowadzą do podobnych wniosków.

Prowadzone rozważania dają podstawową wiedzę w zakresie zmian w strukturze ludności, która niezbędna jest do poprawnego formułowania polityki społeczno-gospodarczej w regionach, zwłaszcza w zakresie polityki społecznej oraz ochronie zdrowia. Na szczeblu krajowym odnosi się zaś do planowania wszelkich działań, które mają na celu wyrównywanie szans w rozwoju ekonomicznym tych jednostek przestrzennych.

\section{Metoda analizy}

W prowadzonych rozważaniach za obiekt do porównań przyjęto województwo. Jest to region administracyjny kraju, który charakteryzuje się wysokim stopniem instytucjonalizacji, stanowi podstawową jednostkę strukturyzacji i organizacji przestrzennej $\mathrm{kraju}^{28}$.W analizie za zmienne objaśniające przyjęto miary stopnia zaawansowania starości demograficznej zaproponowane przez M. Podogrodzką ${ }^{29}$ oraz M. Cieślak ${ }^{30}$. Pierwsza $\mathrm{z}$ tych metod polega na porównywaniu rzeczywistych struktur ludności ze strukturą hipotetyczną, która jest arbitralnie ustalana. Różnica odległości między tymi strukturami pozwala na ocenę, jak bardzo rzeczywiste struktury wieku różnią się między przyjętymi w analizie jednostkami geograficznymi oraz jak dalece odbiegają one od przyjętej struktury hipotetycznej. W naszych rozważaniach przyjęliśmy, że strukturę hipotetyczną wyznacza struktura regresywna

${ }^{28}$ Z. Chojnicki, Region w ujęciu geograficzno-systemowym, w: Podstawy regionalizacji geograficznej, red. T. Czyż, Bogucki Wydawnictwo Naukowe, Poznań 1996; T. Czyż, Zastosowanie modelu potencjału w analizie zróżnicowania regionalnego Polski, „Studia Regionalne i Lokalne” 2002, nr 2-3, s. 24-28.

${ }^{29}$ M. Podogrodzka, op.cit.

${ }^{30}$ M. Cieślak, op.cit. 
(odwrócona piramida wieku), określona dla pięcioletnich grup wieku ${ }^{31}$. Natomiast w drugiej propozycji analizuje się asymetrię rozkładu, która dodatkowo ważona jest średnim wiekiem ludności. Im wyższe wartości tej miary, tym bardziej lewostronnie asymetryczny jest rozkład. W obu przypadkach do wyodrębnienia jednorodnych grup województw wykorzystano jedną z metod taksonomicznych, tj. relację między przekrojową średnią arytmetyczną a k-liczbą przekrojowych odchyleń standardowych $^{32}$. W ten sposób utworzono sześć klas, ale tak, że im wyższa grupa, tym bardziej zaawansowany proces starzenia się ludności (tabela 1).

Tabela 1. Kryterium wyodrębnienia jednorodnych grup województw

\begin{tabular}{|l|c|l|c|}
\hline Klasa & $\begin{array}{c}\text { Relacja między średnią (a) } \\
\text { a odchyleniem standardowym (b) }\end{array}$ & Klasa & $\begin{array}{c}\text { Relacja między średnią (a) } \\
\text { a odchyleniem standardowym (b) }\end{array}$ \\
\hline I & $(-\infty ;[a-2 b])$ & IV & $<a ; a+b)$ \\
\hline II & $<a-2 b ; a-b)$ & V & $<a+b ; a+2 b)$ \\
\hline III & $<a-b ; a)$ & VI & $<a+2 b ;+\infty)$ \\
\hline
\end{tabular}

Źródło: Opracowanie własne.

W ocenie dynamiki starzenia się ludności wykorzystano liniową funkcję trendu, a do określenia jej skali również relację między przekrojową średnią arytmetyczną a przekrojowym odchyleniem standardowym, na zasadach wcześniej wyznaczonych.

W pracy wykorzystano dane o ludności według pięcioletnich grup wieku zaczerpnięte ze stron internetowych Eurostatu. Wszystkie analizy statystyczne zostały wykonane przy użyciu programu komputerowego Statistica.

${ }^{31} \mathrm{~W}$ określeniu struktury hipotetycznej przyjęto następującą zasadę:

\begin{tabular}{|c|c|c|c|c|c|c|c|c|c|c|c|c|c|c|c|c|c|}
\hline \multirow{3}{*}{$\begin{array}{c}\text { Udział } \\
\text { ludności } \\
\text { w \% }\end{array}$} & \multicolumn{17}{|c|}{ Grupa wieku } \\
\hline & $0-4$ & $5-9$ & $10-14$ & $15-19$ & 20-24 & $25-29$ & $30-34$ & $35-39$ & 40-44 & 45-49 & $50-54$ & $55-59$ & $60-64$ & $65-69$ & $70-74$ & $75-79$ & $80+$ \\
\hline & 2,5 & 3,0 & 3,5 & 4,0 & 4,5 & 5,0 & 5,5 & 6,0 & 6,5 & 7,0 & 7,5 & 8,0 & 8,5 & 8,0 & 7,5 & 7,0 & 6,0 \\
\hline
\end{tabular}

32 J. Pociecha et al., Metody taksonomiczne w badaniach społeczno-ekonomicznych, PWN, Warszawa 1988; E. Nowak, Metody taksonomiczne w klasyfikacji obiektów społeczno-gospodarczych, PWE, Warszawa 1990; T. Grabiński, Metody taksonometrii, Wydawnictwo AE w Krakowie, Kraków 1992; T. Grabiński et al., Metody taksonomii numerycznej w modelowaniu zjawisk społeczno-gospodarczych, PWN, Warszawa 1989; A. Młodak, Analiza taksonomiczna w statystyce regionalnej, Difin, Warszawa 2006. 


\section{Typologia województw}

\subsection{Metoda podobieństwa struktur}

Syntetyczne miary rozproszenia wskazują, że z czasem struktury wieku ludności stały się nieco bardziej jednorodne, podobne między województwami. Jednocześnie w pierwszych dwóch dekadach badanego okresu systematycznie rosła liczba tych jednostek przestrzennych charakteryzujących się podobną strukturą wieku do przeciętnej przekrojowej, ale po tym okresie nastąpiło odwrócenie tej tendencji. Wyniki te wskazują, że choć przestrzenne struktury wieku ludności stały się nieco bardziej jednorodne, nadal w niektórych województwach były one zdecydowanie odmienne niż w pozostałych. Ponadto we wszystkich województwach odnotowujemy tendencję do spadku różnic między ich strukturami wieku ludności a strukturą regresywną. Z czasem pogłębiał się w nich zatem proces starzenia się ludności (tabela 2).

Tabela 2. Przekrojowe miary statystyczne wskaźnika podobieństwa struktury ludności według wieku w latach 1991-2011

\begin{tabular}{|l|c|c|c|c|c|c|c|c|c|c|c|r|}
\hline $\begin{array}{c}\text { Przekrojowe } \\
\text { miary } \\
\text { statystyczne }\end{array}$ & 1991 & 1993 & 1995 & 1997 & 1999 & 2001 & 2003 & 2005 & 2007 & 2009 & 2011 & Trend \\
\hline Minimum & 0,266 & 0,258 & 0,250 & 0,246 & 0,235 & 0,224 & 0,210 & 0,198 & 0,189 & 0,179 & 0,176 & $-219,888$ \\
\hline Maksimum & 0,343 & 0,338 & 0,327 & 0,312 & 0,302 & 0,288 & 0,268 & 0,252 & 0,238 & 0,227 & 0,221 & $-138,771$ \\
\hline $\begin{array}{l}\text { Obszar } \\
\text { zmienności }\end{array}$ & 0,077 & 0,080 & 0,077 & 0,067 & 0,067 & 0,064 & 0,058 & 0,054 & 0,049 & 0,048 & 0,045 & 81,117 \\
\hline $\begin{array}{l}\text { Średnia } \\
\text { arytmetyczna }\end{array}$ & 0,306 & 0,300 & 0,290 & 0,282 & 0,271 & 0,258 & 0,242 & 0,229 & 0,216 & 0,206 & 0,202 & $-171,079$ \\
\hline $\begin{array}{l}\text { Odchylenie } \\
\text { standardowe }\end{array}$ & 0,022 & 0,021 & 0,019 & 0,018 & 0,017 & 0,016 & 0,015 & 0,014 & 0,013 & 0,013 & 0,014 & 24,246 \\
\hline $\begin{array}{l}\text { Współczynnik } \\
\text { zmienności }\end{array}$ & 7,143 & 6,988 & 6,610 & 6,451 & 6,422 & 6,286 & 6,240 & 6,164 & 6,030 & 6,530 & 6,680 & 14,173 \\
\hline
\end{tabular}

Źródło: Obliczenia własne na podstawie danych Eurostatu.

Niezależnie od badanego roku, możemy wyróżnić sześć grup województw odznaczających się zbliżoną strukturą wieku ludności. Jednakże zarówno liczba tych jednostek przestrzennych w tych grupach ulegała zmianie, jak i same jednostki. Spowodowało to, że ich przestrzenny obraz także się zmieniał. Z czasem stał się on jeszcze bardziej zróżnicowany. Województwa charakteryzujące się podobną strukturą wieku ludności były rozlokowane w różnych częściach kraju i tym samym nie tworzyły zwartych obszarów. Jednocześnie większość województw odznaczających się relatywnie młodą strukturą wieku, tj. większym oddaleniem rzeczywistej struktury 
wieku od struktury typu regresywnego, znajdowała się w części Polski Północnej i Zachodniej. Natomiast część centralna oraz północno-wschodnia kraju to obszar, w których struktury te były zbliżone do struktury hipotetycznej. We wszystkich województwach odnotowujemy postępujący proces starzenia się ludności, ale brak jest wyraźnego skorelowania między tą dynamiką a stanem wyjściowym. W tych województwa, gdzie w latach 90. struktura wieku ludności była podobna, tempo starzenia się ludności mogło przebiegać $\mathrm{z}$ różnym natężeniem. Można jednak zauważyć, że na terenach Polski Zachodniej, tam gdzie województwa odznaczały się względnie młodą strukturą wieku, proces starzenia się ludności był intensywniejszy w stosunku do tych obszarów, gdzie struktury ludności były już i tak zbliżone do struktury regresywnej (rysunek 1).

\section{Rysunek 1. Wskaźnik podobieństwa struktury ludności według wieku i województw w latach 1991, 2001 i 2011}

\begin{tabular}{|c|c|c|c|c|c|c|}
\hline $1991^{a}$ & $2001^{a}$ & Trend $^{\mathrm{a}}$ & \multicolumn{2}{c|}{$\begin{array}{c}\text { Klasa } \\
\text { wartości }\end{array}$} \\
\hline
\end{tabular}

a Im kolor jaśniejszy, tym mniejsza różnica między rzeczywistą strukturą wieku a strukturą hipotetyczną.

${ }^{\mathrm{b}}$ Im kolor jaśniejszy, tym wolniejsze natężenie zmian.

Źródło: Opracowanie własne z wykorzystaniem pakietu komputerowego Statistica.

Z czasem w populacji kobiet również zmalały różnice w strukturze wieku między województwami. Odnotowujemy też, że do 2007 r. stale rosła liczba województw odznaczająca się podobną strukturą jak średnia przekrojowa. Po tym okresie nastąpił jednakże spadek tej liczby, co oznacza, że mimo tendencji do wzrostu przestrzennych podobieństw w strukturze wieku nadal były też i takie województwa, w których były one zdecydowanie odmienne w stosunku do pozostałych. We wszystkich województwach odnotowano zatem pogłębiający się proces starzenia się ludności, ale o różnej intensywności (tabela 3). 
Tabela 3. Przekrojowe miary statystyczne wskaźnika podobieństwa struktury kobiet według wieku w latach 1991-2011

\begin{tabular}{|l|c|c|c|c|c|c|c|c|c|c|c|c|}
\hline $\begin{array}{l}\text { Przekrojowe } \\
\text { miary } \\
\text { statystyczne }\end{array}$ & 1991 & 1993 & 1995 & 1997 & 1999 & 2001 & 2003 & 2005 & 2007 & 2009 & 2011 & Trend \\
\hline Minimum & 0,236 & 0,227 & 0,218 & 0,213 & 0,202 & 0,191 & 0,179 & 0,168 & 0,157 & 0,148 & 0,146 & $-229,685$ \\
\hline Maksimum & 0,321 & 0,315 & 0,304 & 0,289 & 0,277 & 0,263 & 0,242 & 0,225 & 0,211 & 0,201 & 0,198 & $-137,454$ \\
\hline $\begin{array}{l}\text { Obszar } \\
\text { zmienności }\end{array}$ & 0,085 & 0,088 & 0,086 & 0,076 & 0,075 & 0,072 & 0,063 & 0,056 & 0,054 & 0,053 & 0,052 & 92,231 \\
\hline $\begin{array}{l}\text { Średnia } \\
\text { arytmetyczna }\end{array}$ & 0,280 & 0,274 & 0,264 & 0,255 & 0,244 & 0,230 & 0,214 & 0,202 & 0,190 & 0,181 & 0,178 & $-172,769$ \\
\hline $\begin{array}{l}\text { Odchylenie } \\
\text { standardowe }\end{array}$ & 0,024 & 0,023 & 0,021 & 0,020 & 0,019 & 0,018 & 0,017 & 0,015 & 0,015 & 0,015 & 0,015 & 27,022 \\
\hline $\begin{array}{l}\text { Współczynnik } \\
\text { zmienności }\end{array}$ & 8,482 & 8,378 & 8,087 & 7,938 & 7,952 & 7,881 & 7,741 & 7,323 & 7,689 & 8,322 & 8,493 & 15,640 \\
\hline
\end{tabular}

Źródło: Obliczenia własne na podstawie danych Eurostatu.

Stale w czasie możemy wyodrębnić sześć grup województw o podobnej strukturze wieku kobiet. Równocześnie wyraźnej zmianie ulegała zarówno liczba jednostek wchodzących w ich skład, jak i same jednostki. Zmieniało się zatem też ich przestrzenne położenie oraz w różnych częściach kraju województwa charakteryzowały się podobną strukturą wieku. O ile jeszcze w pierwszych dwóch dekadach badanego okresu możemy zauważyć, że większość tych jednostek odznaczająca się wyraźnie odmienną strukturą wieku od regresywnej położona była w części Polski Północnej i Zachodniej, a te, dla których była ona zbliżona do hipotetycznej, znajdowały się w części centralnej, to już w kolejnych latach obraz ten nie był już tak jednorodny. Województwa o podobnej strukturze wieku rozlokowane były w różnych częściach kraju, tworząc małoelementowe skupiska. Nie odnotowaliśmy też wyraźnej przestrzennej zależności między dynamiką zbiegania struktury wieku kobiet do struktury regresywnej a strukturą wieku odnotowaną na początku tego okresu. Jednakże w większości województw, w których struktura wieku była już relatywnie stara, natężenie tych zmian był słabsze w porównaniu z tymi jednostkami administracyjnymi, w których struktura ta była względnie młoda (rysunek 2). 


\section{Rysunek 2. Wskaźnik podobieństwa struktury kobiet według wieku i województw w latach 1991, 2001 i 2011}

\begin{tabular}{|c|c|c|c|c|c|}
\hline $1991^{a}$ & $2001^{a}$ & Trend $^{\mathrm{a}}$ & $\begin{array}{c}\text { Klasa } \\
\text { wartości }\end{array}$ \\
\hline
\end{tabular}

a Im kolor jaśniejszy, tym mniejsza różnica między rzeczywistą strukturą wieku a strukturą hipotetyczną.

${ }^{\mathrm{b}}$ Im kolor jaśniejszy, tym wolniejsze natężenie zmian.

Źródło: Opracowanie własne z wykorzystaniem pakietu komputerowego Statistica.

Ujednolicanie się przestrzennych struktur wieku odnotowujemy również w zbiorowości mężczyzn. Z czasem rośnie też liczba województw charakteryzująca się podobną strukturą do średniej przekrojowej, co wskazuje, że maleje liczba jednostek, w których struktura ta była zdecydowanie odmienna. Ponadto z czasem we wszystkich województwach postępuje proces zbiegania rzeczywistych struktur wieku do struktury progresywnej, tj. starzenie się populacji mężczyzn, ale o różnym nasileniu (tabela 4).

Tabela 4. Przekrojowe miary statystyczne wskaźnika podobieństwa struktury mężczyzn według wieku w latach1991-2011

\begin{tabular}{|l|c|c|c|c|c|c|c|c|c|c|c|c|}
\hline $\begin{array}{c}\text { Miary } \\
\text { statystyczne }\end{array}$ & 1991 & 1993 & 1995 & 1997 & 1999 & 2001 & 2003 & 2005 & 2007 & 2009 & 2011 & Trend \\
\hline Minimum & 0,299 & 0,291 & 0,285 & 0,281 & 0,270 & 0,260 & 0,247 & 0,236 & 0,224 & 0,213 & 0,210 & $-214,929$ \\
\hline Maksimum & 0,366 & 0,362 & 0,351 & 0,338 & 0,328 & 0,314 & 0,296 & 0,280 & 0,267 & 0,254 & 0,249 & $-142,828$ \\
\hline $\begin{array}{l}\text { Obszar } \\
\text { zmienności }\end{array}$ & 0,067 & 0,071 & 0,066 & 0,057 & 0,058 & 0,055 & 0,049 & 0,044 & 0,043 & 0,041 & 0,039 & 72,101 \\
\hline Średnia & 0,333 & 0,328 & 0,318 & 0,310 & 0,299 & 0,287 & 0,272 & 0,259 & 0,245 & 0,234 & 0,230 & $-173,172$ \\
\hline $\begin{array}{l}\text { Odchylenie } \\
\text { standardowe }\end{array}$ & 0,020 & 0,019 & 0,017 & 0,016 & 0,015 & 0,014 & 0,013 & 0,012 & 0,012 & 0,012 & 0,012 & 23,113 \\
\hline $\begin{array}{l}\text { Współczynnik } \\
\text { zmienności }\end{array}$ & 5,929 & 5,730 & 5,284 & 5,196 & 5,078 & 4,893 & 4,825 & 4,679 & 4,745 & 4,959 & 5,127 & 13,347 \\
\hline
\end{tabular}

Źródło: Obliczenia własne na podstawie danych Eurostatu.

W rozważanej zbiorowości możemy wyróżnić sześć grup województw, które odznaczają się wyraźnie odmienną strukturą wieku mężczyzn. Jednocześnie z czasem zmienia się w nich zarówno liczba jednostek przestrzennych, jak i same województwa. Sprawia to, że przestrzenny ich obraz również nie jest stabilny w czasie i nie 
zawsze województwa charakteryzujące się podobną strukturą wieku tworzą zwarte przestrzennie obszary. Można jednak zauważyć, że w latach 90. większość jednostek o relatywnie młodej strukturze wieku rozlokowana była w części północnej i wschodniej kraju. Dwie dekady później sytuacja uległa nieco zmianie. Do części Polski Północnej dołączyły obszary wschodnie kraju. W badanym okresie przestrzenna dynamika starzenia się zbiorowości mężczyzn nie była zależna od wyjściowej struktury wieku. To samo nasilenie zmian dotyczyło jednostek zarówno o relatywnie młodej, jak i starej strukturze wieku. Jednakże w większości województw, w których struktura wieku mężczyzna zdecydowanie odbiegała od struktury progresywnej, tempo starzenia się tej populacji było intensywniejsze aniżeli tam, gdzie była ona już i tak względnie stara (rysunek 3).

\section{Rysunek 3. Wskaźnik podobieństwa struktury mężczyzn według wieku i województw w latach 1991, 2001 i 2011}

\begin{tabular}{|c|c|c|c|c|c|}
\hline $1991^{\mathrm{a}}$ & $2001^{\mathrm{a}}$ & Trend $^{\mathrm{b}}$ & $\begin{array}{c}\text { Klasa } \\
\text { wartości }\end{array}$ \\
\hline
\end{tabular}

a Im kolor jaśniejszy, tym mniejsza różnica między rzeczywistą strukturą wieku a strukturą hipotetyczną.

${ }^{\mathrm{b}}$ Im kolor jaśniejszy, tym wolniejsze natężenie zmian.

Źródło: Opracowanie własne z wykorzystaniem pakietu komputerowego Statistica.

Do oceny różnic w natężeniu oraz dynamice starzenia się populacji kobiet i mężczyzn wyznaczyliśmy wskaźnik feminizacji. Miara ta pokazuje, jak dalece struktura wieku kobiet różni się w porównaniu ze strukturą wieku mężczyzn w odniesieniu do struktury regresywnej ${ }^{33}$. Syntetyczne miary rozproszenia wskazują, że z czasem ich wartości rosły, co oznacza, że wzrosły też przestrzenne dysproporcje między tymi strukturami wieku. Jednocześnie we wszystkich tych jednostkach przestrzennych stopień zaawansowania starości demograficznej był wyższy w populacji kobiet niż mężczyzn i dodatkowo z czasem różnice te jeszcze pogłębiły się (tabela 5).

33 Miara ta wyznaczona została jako iloraz miary podobieństwa kobiet do miary podobieństwa mężczyzn. 
Tabela 5. Przekrojowe miary statystyczne wskaźnika podobieństwa struktury wskaźnika feminizacji według wieku w latach 1991-2011

\begin{tabular}{|l|c|c|c|c|c|c|c|c|c|c|c|c|}
\hline $\begin{array}{c}\text { Miary } \\
\text { statystyczne }\end{array}$ & 1991 & 1993 & 1995 & 1997 & 1999 & 2001 & 2003 & 2005 & 2007 & 2009 & 2011 & Trend \\
\hline Minimalny & 0,789 & 0,779 & 0,765 & 0,759 & 0,748 & 0,736 & 0,723 & 0,712 & 0,702 & 0,694 & 0,695 & 0,908 \\
\hline Maksymalny & 0,877 & 0,871 & 0,866 & 0,854 & 0,844 & 0,836 & 0,816 & 0,803 & 0,802 & 0,811 & 0,818 & 1,073 \\
\hline $\begin{array}{l}\text { Obszar } \\
\text { zmienności }\end{array}$ & 0,088 & 0,092 & 0,101 & 0,095 & 0,095 & 0,100 & 0,093 & 0,091 & 0,100 & 0,117 & 0,123 & 0,164 \\
\hline Średnia & 0,840 & 0,834 & 0,829 & 0,820 & 0,813 & 0,802 & 0,786 & 0,779 & 0,773 & 0,771 & 0,772 & 0,995 \\
\hline $\begin{array}{l}\text { Odchylenie } \\
\text { standardowe }\end{array}$ & 0,024 & 0,025 & 0,027 & 0,026 & 0,027 & 0,028 & 0,028 & 0,024 & 0,027 & 0,031 & 0,031 & 0,045 \\
\hline $\begin{array}{l}\text { Współczynnik } \\
\text { zmienności }\end{array}$ & 2,869 & 2,978 & 3,201 & 3,176 & 3,349 & 3,520 & 3,576 & 3,135 & 3,518 & 3,978 & 4,069 & 4,552 \\
\hline
\end{tabular}

Źródło: Obliczenia własne na podstawie danych Eurostatu.

W pierwszej dekadzie badanego okresu możemy wyodrębnić cztery grupy województw, w których różnica między miarą podobieństwa struktur dla kobiet a miarą podobieństwa dla mężczyzn była podobna. W kolejnych latach grup tych było już pięć. Zmieniała się też liczba województw wchodzących w skład tych grup oraz same te jednostki. Przestrzenny obraz wskaźnika feminizacji nie był zatem stabilny w czasie. W pierwszych dwóch dekadach badanego okresu większość województw, dla których różnica między stopniem zaawansowania starości demograficznej w populacji kobiet była znacznie wyższa aniżeli w populacji mężczyzn, rozlokowana była przede wszystkim w północnej części kraju. Dekadę później nadal te obszary charakteryzowały się relatywnie wysokimi wartościami wskaźnika feminizacji, ale w części południowo-wschodniej i centralnej były one już zdecydowanie wyższe. Natomiast najniższe różnice odnotowaliśmy w początkowych latach w części Polski Środkowowschodniej, a następnie już tylko w jej części wschodniej. Nie zaobserwowano zaś wyraźnej przestrzennej zależności między wartością wskaźnika feminizacji a jego natężeniem zmian. Jednakże większość województw charakteryzująca się niską dynamiką położona była w północno-wschodniej części kraju, a wysoką w części centralnej. Oznacza to, że w pierwszym przypadku szybkość upodobniania się struktur wieku kobiet do struktur wieku mężczyzn była wolniejsza niż w tym drugim przypadku (rysunek 4). 
Rysunek 4. Wskaźnik podobieństwa struktury wskaźnika feminizacji według województw w latach 1991, 2001 i 2011

\begin{tabular}{|c|c|c|c|c|c|}
\hline $1991^{\mathrm{a}}$ & $2001^{\mathrm{a}}$ & Trend $^{\mathrm{b}}$ & \multicolumn{2}{c|}{$\begin{array}{c}\text { Klasa } \\
\text { wartości }\end{array}$} \\
\hline
\end{tabular}

${ }^{a}$ Im kolor jaśniejszy, tym mniejsza różnica między strukturą wieku kobiet a strukturą wieku mężczyzn.

${ }^{\mathrm{b}}$ Im kolor jaśniejszy, tym wolniejsze natężenie zmian.

Źródło: Opracowanie własne z wykorzystaniem pakietu komputerowego Statistica.

\subsection{Metoda asymetrii rozkładu}

Z czasem odnotowujemy spadek przestrzennych różnic w wartości miary asymetrii i wzrost liczby województw przyjmujących wartości bliskie średniej przekrojowej, o czym informują nas malejące wartości obszaru zmienności oraz współczynnika zmienności. Oznacza to, że struktury ludności według wieku stają się coraz to bardziej podobne w badanych jednostkach. Równocześnie asymetria tego rozkładu rosła z czasem, ale jej wzrost był wyraźnie zróżnicowany przestrzennie. $Z$ różnym nasileniem postępował $\mathrm{w}$ nich zatem proces starzenia się ludności (tabela 6).

Tabela 6. Przekrojowe miary statystyczne miary asymetrii struktury ludności według wieku w latach 1991-2011

\begin{tabular}{|l|r|r|r|r|r|r|r|r|r|r|r|r|}
\hline $\begin{array}{c}\text { Miary } \\
\text { statystyczne }\end{array}$ & 1991 & 1993 & 1995 & 1997 & 1999 & 2001 & 2003 & 2005 & 2007 & 2009 & 2011 & Trend \\
\hline Minimum & 65,49 & 68,39 & 71,19 & 74,03 & 76,94 & 79,68 & 83,68 & 86,40 & 88,58 & 91,85 & 93,63 & 0,69 \\
\hline Maksimum & 91,31 & 94,12 & 94,76 & 96,26 & 97,90 & 97,54 & 100,87 & 101,10 & 103,19 & 104,93 & 105,02 & 1,48 \\
\hline $\begin{array}{l}\text { Obszar } \\
\text { zmienności }\end{array}$ & 25,82 & 25,72 & 23,57 & 22,23 & 20,96 & 17,86 & 17,20 & 14,70 & 14,61 & 13,08 & 11,39 & 0,79 \\
\hline Średnia & 77,38 & 79,86 & 82,04 & 84,17 & 86,65 & 88,63 & 91,61 & 93,61 & 95,63 & 98,11 & 99,10 & 1,15 \\
\hline $\begin{array}{l}\text { Odchylenie } \\
\text { standardowe }\end{array}$ & 7,05 & 6,90 & 6,40 & 6,12 & 5,83 & 5,34 & 5,18 & 4,73 & 4,51 & 4,05 & 3,74 & 0,22 \\
\hline $\begin{array}{l}\text { Współczynnik } \\
\text { zmienności }\end{array}$ & 9,11 & 8,64 & 7,80 & 7,27 & 6,73 & 6,03 & 5,65 & 5,05 & 4,71 & 4,13 & 3,77 & 19,60 \\
\hline
\end{tabular}

Źródło: Obliczenia własne na podstawie danych Eurostatu. 
Niezależnie od roku badania można wyodrębnić pięć grup województw podobnych ze względu na wartość miary asymetrii, ale województwa przynależne do danej grupy nie zawsze posiadały jedną wspólną granicę. Rozlokowane były w różnych częściach kraju. Ponadto w czasie zmieniała się też ich liczba oraz skład, co oznacza, że ich przestrzenny obraz nie był stabilny w czasie. Można jednak zauważyć, że większość województw charakteryzująca się relatywnie małą wartością miary asymetrii znajdowała się przede wszystkim w części północnej i zachodniej kraju. Natomiast te o najwyższych jej wartościach rozlokowane były głównie w części środkowej. Zatem ludność zamieszkała na terenach Polski Północnej i Zachodniej była relatywnie młodsza od tej, która zamieszkiwała pozostałe obszary kraju. Jednocześnie to samo tempo starzenia się ludności dotyczyło województw o różnym stopniu zaawansowania starości demograficznej. Nie odnotowaliśmy bowiem istotnej przestrzennej zależności między wartością miary asymetrii a jej zmianami w czasie. Jednakże większość województw o relatywnie wysokiej dynamice znajdowała się w północnej części kraju, a o najsłabszej w części środkowej. W pierwszym przypadku były to raczej te jednostki, które odznaczały się względnie młodą strukturą wieku ludności, a w tym drugim relatywnie starą (rysunek 5).

\section{Rysunek 5. Miara asymetrii struktury ludności według wieku i województw w latach 1991, 2001 i 2011}

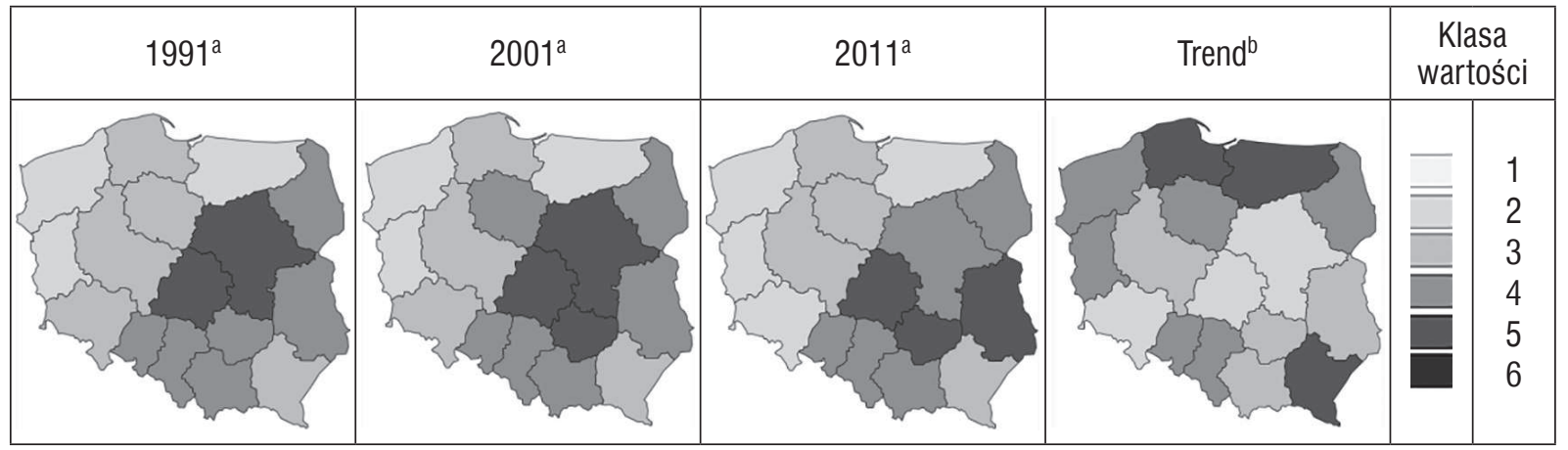

${ }^{a}$ Im kolor ciemniejszy, tym rozkład coraz bardziej lewostronnie asymetryczny.

${ }^{\mathrm{b}}$ Im kolor jaśniejszy, tym wolniejsze natężenie zmian.

Źródło: Opracowanie własne z wykorzystaniem pakietu komputerowego Statistica.

W populacji kobiet odnotowano również przestrzenne ujednolicanie się struktur wieku (z czasem maleją wartości miar rozproszenia), ale i wzrost, z różną intensywnością, siły asymetrii tych rozkładów. We wszystkich województwach populacja kobiet starzeje się i we wszystkich tych jednostkach stopień zaawansowania tego procesu staje się coraz to bardziej podobny (tabela 7). 
Tabela 7. Przekrojowe miary statystyczne miary asymetrii struktury kobiet według wieku w latach 1991-2011

\begin{tabular}{|l|r|r|r|r|r|r|r|r|r|r|r|r|}
\hline $\begin{array}{l}\text { Miary } \\
\text { statystyczne }\end{array}$ & 1991 & 1993 & 1995 & 1997 & 1999 & 2001 & 2003 & 2005 & 2007 & 2009 & 2011 & Trend \\
\hline Minimum & 70,79 & 74,06 & 77,26 & 80,53 & 83,97 & 86,88 & 91,92 & 94,52 & 96,91 & 99,66 & 101,03 & 0,61 \\
\hline Maksimum & 102,87 & 106,01 & 106,69 & 108,11 & 109,77 & 109,00 & 112,88 & 112,93 & 114,56 & 116,29 & 116,80 & 1,68 \\
\hline $\begin{array}{l}\text { Obszar } \\
\text { zmienności }\end{array}$ & 32,08 & 31,95 & 29,43 & 27,58 & 25,80 & 22,12 & 20,96 & 18,41 & 17,65 & 16,63 & 15,77 & 1,07 \\
\hline Średnia & 85,44 & 88,19 & 90,58 & 92,84 & 95,57 & 97,59 & 101,08 & 103,05 & 105,21 & 107,16 & 108,01 & 1,21 \\
\hline $\begin{array}{l}\text { Odchylenie } \\
\text { standardowe }\end{array}$ & 8,78 & 8,58 & 7,99 & 7,63 & 7,29 & 6,86 & 6,76 & 6,35 & 6,00 & 5,67 & 5,38 & 0,29 \\
\hline $\begin{array}{l}\text { Współczynnik } \\
\text { zmienności }\end{array}$ & 10,28 & 9,73 & 8,83 & 8,21 & 7,63 & 7,03 & 6,69 & 6,16 & 5,70 & 5,29 & 4,98 & 23,88 \\
\hline
\end{tabular}

Źródło: Obliczenia własne na podstawie danych Eurostatu.

W pierwszej dekadzie badanego okresu grupy województw charakteryzujące się podobnym poziomem wartości miary asymetrii tworzyły raczej zwarte przestrzennie obszary. W skupiskach tych, a było ich cztery, nie zmieniła się liczba województw, a jedynie nieznacznie ich skład. Województwa położone w północnej i zachodniej części Polski odznaczały się relatywnie młodszą strukturą wieku kobiet niż na pozostałym obszarze, a zwłaszcza w jej części centralnej. W 2011 r. obraz ten uległ nieco zmianie. Wzrosła liczba grup województw podobnych oraz nie zawsze obiekty wchodzące w ich skład miały co najmniej jedną wspólną granicę. Nadal jednak większość województw odznaczająca się względnie młodą strukturą wieku położona była w części północnej i zachodniej kraju, ale te, dla których miara asymetrii przyjmowała najwyższe wartości, rozlokowane były już w części wschodniej i środkowopołudniowej kraju. Nie odnotowaliśmy zaś istotnego przestrzennego skorelowania między wartością miary asymetrii a jej zmianami w czasie. W tych województwach, w których struktura wieku kobiet była podobna, dynamika procesu starzenia się mogła być odmienna. Jednakże w większości tych jednostek przestrzennych, gdzie odnotowujemy relatywnie młodą strukturę wieku kobiet, proces starzenia się był intensywniejszy niż tam, gdzie struktury te były już i tak zaawansowane (rysunek 6). 


\section{Rysunek 6. Miara asymetrii struktury kobiet według wieku i województw} w latach 1991, 2001 i 2011

\begin{tabular}{|c|c|c|c|c|c|}
\hline $1991^{\mathrm{a}}$ & $2001^{\mathrm{a}}$ & Trend $^{\mathrm{b}}$ & $\begin{array}{c}\text { Klasa } \\
\text { wartości }\end{array}$ \\
\hline
\end{tabular}

${ }^{a}$ Im kolor ciemniejszy, tym rozkład coraz bardziej lewostronnie asymetryczny.

${ }^{\mathrm{b}}$ Im kolor jaśniejszy, tym wolniejsze natężenie zmian.

Źródło: Opracowanie własne z wykorzystaniem pakietu komputerowego Statistica.

Zmiany w wartościach syntetycznych miar rozproszenia wskazują, że w populacji mężczyzn również następuje przestrzenne upodabnianie się struktur wieku. Ponadto we wszystkich województwach proces starzenia pogłębiał się z czasem, ale $\mathrm{z}$ różną $\mathrm{w}$ nich intensywnością (tabela 8 ).

Tabela 8. Przekrojowe miary statystyczne miary asymetrii struktury mężczyzn według wieku w latach 1991-2011

\begin{tabular}{|l|c|c|c|c|c|c|c|c|c|c|c|c|}
\hline $\begin{array}{l}\text { Miary } \\
\text { statystyczne }\end{array}$ & 1991 & 1993 & 1995 & 1997 & 1999 & 2001 & 2003 & 2005 & 2007 & 2009 & 2011 & Trend \\
\hline Minimum & 60,89 & 63,52 & 66,02 & 68,53 & 71,10 & 73,69 & 76,86 & 79,50 & 81,47 & 84,72 & 86,30 & 0,73 \\
\hline Maksimum & 80,83 & 83,23 & 83,85 & 85,31 & 86,90 & 87,17 & 89,95 & 90,79 & 92,58 & 95,06 & 95,59 & 1,36 \\
\hline $\begin{array}{l}\text { Obszar } \\
\text { zmienności }\end{array}$ & 19,94 & 19,71 & 17,83 & 16,79 & 15,80 & 13,48 & 13,09 & 11,29 & 11,11 & 10,34 & 9,29 & 0,63 \\
\hline Średnia & 70,47 & 72,72 & 74,70 & 76,69 & 78,96 & 80,95 & 83,52 & 85,59 & 87,46 & 90,31 & 91,37 & 1,09 \\
\hline $\begin{array}{l}\text { Odchylenie } \\
\text { standardowe }\end{array}$ & 5,57 & 5,41 & 4,98 & 4,75 & 4,49 & 4,10 & 3,97 & 3,62 & 3,43 & 3,11 & 2,88 & 0,20 \\
\hline $\begin{array}{l}\text { Współczynnik } \\
\text { zmienności }\end{array}$ & 7,91 & 7,44 & 6,66 & 6,20 & 5,68 & 5,07 & 4,75 & 4,23 & 3,92 & 3,44 & 3,15 & 17,92 \\
\hline
\end{tabular}

Źródło: Opracowanie własne z wykorzystaniem pakietu komputerowego Statistica.

Grupy województw charakteryzujące się podobnym stopniem zaawansowania starości demograficznej w populacji mężczyzn nie uległy zmianie między rokiem 1999 a 2001. Odnotowano cztery takie skupiska, które były dość zwarte przestrzennie. Część Polski Północnej i Zachodniej charakteryzowała się młodszą struktura wieku mężczyzn aniżeli jej część wschodnia, a zwłaszcza centralna. Dekadę później sytuacja uległa nieco zmianie. Nie zmieniła się wprawdzie liczba grup województw podobnych, ale zmienił się ich skład oraz liczba województw wchodzących do tych 
skupisk. Tym samym przestrzenny obraz również nieco się zmienił. Teraz województwa położone w części zachodniej, południowo-wschodniej i północno-wschodniej odznaczały się młodszą strukturą wieku aniżeli te, które znajdowały się na pozostałym obszarze kraju, a zwłaszcza w części środkowopołudniowej. Przestrzenna dynamika procesu starzenia się mężczyzn nie zależała istotnie od jego natężenia, ale w części północnej i zachodniej, gdzie województwa charakteryzowały się relatywnie młodą strukturą wieku, była ona wyraźniejsza aniżeli w części centralnej i wschodniej Polski, gdzie starość demograficzna była już i tak znacznie zaawansowana (rysunek 7).

Rysunek 7. Miara asymetrii struktury mężczyzn według wieku i województw w latach 1991, 2001 i 2011

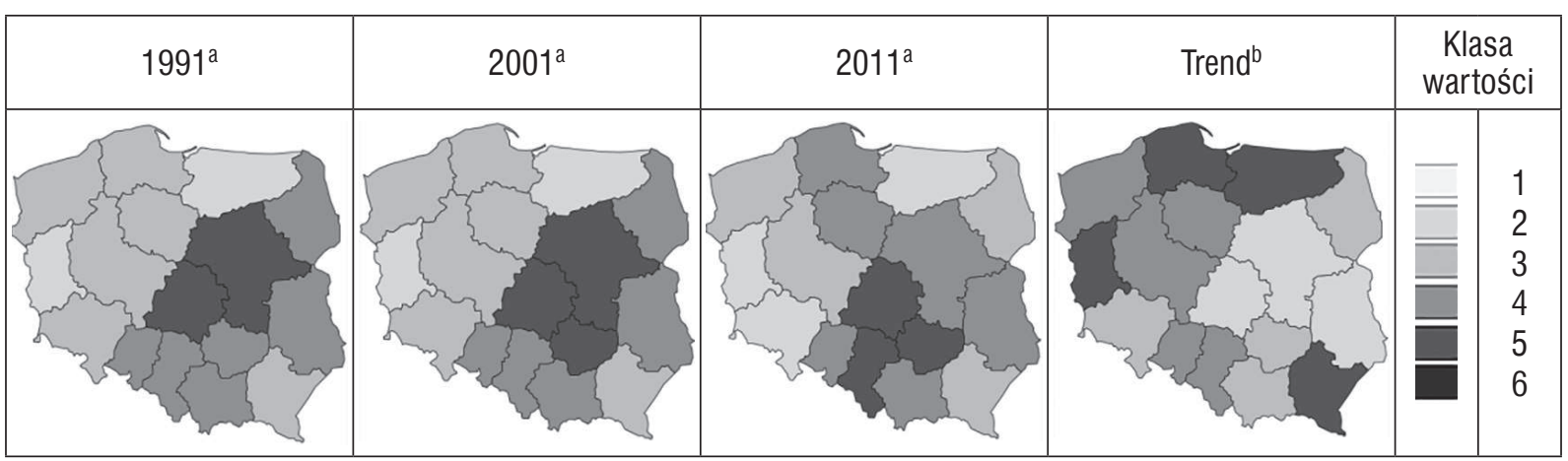

${ }^{a}$ Im kolor ciemniejszy, tym rozkład coraz bardziej lewostronnie asymetryczny.

${ }^{\mathrm{b}}$ Im kolor jaśniejszy, tym wolniejsze natężenie zmian.

Źródło: Opracowanie własne z wykorzystaniem pakietu komputerowego Statistica.

Do oceny przestrzennych różnic w stopniu zaawansowania starości demograficznej populacji kobiet w stosunku do populacji mężczyzn (wskaźnik feminizacji) wykorzystano syntetyczne miary rozproszenia. Wskazują one, że z czasem pogłębiły się te przestrzenne dysproporcje oraz że spadła liczba województw charakteryzująca się zbliżoną wartością do średniej przekrojowej. Województwa stały się jeszcze bardziej zróżnicowane. Mimo że struktura wieku kobiet jest w nich stale starsza od struktury wieku mężczyzn, to z czasem obserwujemy w niektórych województwach zmniejszanie się tych różnic (dotyczy to $10 \mathrm{z}$ nich), a w niektórych dalsze pogłębiania (w 6 jednostkach) (tabela 9). 
Tabela 9. Przekrojowe miary statystyczne miary asymetrii struktury wskaźnika feminizacji według wieku w latach 1991-2011

\begin{tabular}{|l|c|c|c|c|c|c|c|c|c|c|c|c|}
\hline $\begin{array}{c}\text { Miary } \\
\text { statystyczne }\end{array}$ & 1991 & 1993 & 1995 & 1997 & 1999 & 2001 & 2003 & 2005 & 2007 & 2009 & 2011 & Trend \\
\hline Minimum & 1,15 & 1,16 & 1,16 & 1,16 & 1,16 & 1,15 & 1,15 & 1,15 & 1,15 & 1,13 & 1,13 & $-0,061$ \\
\hline Maksimum & 1,27 & 1,27 & 1,27 & 1,27 & 1,26 & 1,25 & 1,27 & 1,28 & 1,27 & 1,27 & 1,27 & 0,007 \\
\hline $\begin{array}{l}\text { Obszar } \\
\text { zmienności }\end{array}$ & 0,12 & 0,11 & 0,11 & 0,11 & 0,10 & 0,10 & 0,12 & 0,13 & 0,13 & 0,13 & 0,14 & 0,068 \\
\hline Średnia & 1,21 & 1,21 & 1,21 & 1,21 & 1,21 & 1,20 & 1,21 & 1,20 & 1,20 & 1,19 & 1,18 & $-0,006$ \\
\hline $\begin{array}{l}\text { Odchylenie } \\
\text { standardowe }\end{array}$ & 0,03 & 0,03 & 0,03 & 0,03 & 0,03 & 0,03 & 0,04 & 0,04 & 0,04 & 0,04 & 0,04 & 0,015 \\
\hline $\begin{array}{l}\text { Współczynnik } \\
\text { zmienności }\end{array}$ & 2,76 & 2,66 & 2,60 & 2,54 & 2,58 & 2,73 & 2,98 & 3,21 & 3,23 & 3,42 & 3,49 & 262,200 \\
\hline
\end{tabular}

Źródło: Obliczenia własne na podstawie danych Eurostatu.

W badanym okresie nieco zmieniała się też liczba grup województw charakteryzujących się podobnym poziomem wartości wskaźnika feminizacji (najpierw pięć, a później cztery i znowu pięć), liczba województw przynależna do tych skupisk oraz same te jednostki. W konsekwencji grupy te były relatywnie mało zwarte przestrzennie i województwa charakteryzujące się podobnym poziomem wartości tej miary rozlokowane były w różnych częściach kraju. W $1991 \mathrm{r}$. najwięcej województw, w których różnica między stopniem zaawansowania starości demograficznej była relatywnie niewielka między populacją kobiet i mężczyzn, znajdowała się w części północnej i północno-zachodniej kraju. Natomiast te, w których różnica ta była bardzo wyraźna, rozlokowane były w części środkowej Polski. Zbliżony obraz odnotowujemy również w kolejnej dekadzie. W 2011 r. przedstawia się on już nieco inaczej, ponieważ wyraźnie ściana Polski Zachodniej odznaczała się znacznie mniejszymi różnicami w strukturze wieku kobiet i mężczyzn niż jej część wschodnia. Jednocześnie dynamika zmniejszania się tych różnic nie zależała od wartości wskaźnika feminizacji na początku badanego okresu, ale w większości województw położonych w Polsce Północnej i Południowo-Wschodniej proces ten przebiegał szybciej, jak w części południowo-zachodniej i południowo-wschodniej (rysunek 8). 
Rysunek 8. Miara asymetrii struktury wskaźnika feminizacji według wieku i województw w latach 1991, 2001 i 2011

\begin{tabular}{|c|c|c|c|c|c|}
\hline $1991^{\mathrm{a}}$ & $2001^{\mathrm{a}}$ & Trend $^{\mathrm{b}}$ & $\begin{array}{c}\text { Klasa } \\
\text { wartości }\end{array}$ \\
\hline
\end{tabular}

a Im kolor jaśniejszy, tym mniejsza różnica między strukturą wieku kobiet a strukturą wieku mężczyzn.

${ }^{\mathrm{b}}$ Im kolor jaśniejszy, tym wolniejsze natężenie zmian.

Źródło: Opracowanie własne z wykorzystaniem pakietu komputerowego Statistica.

\section{Porównanie wyników}

Niezależnie od przyjętej metody, tj. podobieństwa struktur (P) czy miary asymetrii (C), ocena przestrzennego zróżnicowania starości demograficznej jest podobna. Z czasem odnotowujemy ujednolicanie się struktur wieku ludności zarówno w populacji kobiet, jak i mężczyzn, a tempo tych zmian nie jest zależne od struktury zaobserwowanej na początku badanego okresu. Stopień zaawansowania starości demograficznej był także zawsze wyższy w populacji kobiet aniżeli mężczyzn.

W celu oceny zbieżności delimitacji obszarów podobnych w stopniu zaawansowania starości demograficznej metodą podobieństwa struktur $(\mathrm{P})$ oraz miarą asymetrii (C) wykorzystaliśmy informacje o przynależności województw do poszczególnych grup. Każdej jednostce przyporządkowaliśmy odpowiedni numer skupiska i porównaliśmy, czy numery te są podobne w przypadku obu tych metod. Ponieważ zakres zmienności wartości charakterystyki opisującej stopień zaawansowania starości demograficznej wyznaczonej metodą podobieństwa struktur oraz metodą asymetrii był zdecydowanie odmienny, tworząc klasy ich wartości, na podstawie relacji między przekrojową średnią arytmetyczną a odchyleniem standardowym, uzyskaliśmy różną ich liczbę (poza wskaźnikiem feminizacji). Przyjmując, że jeżeli różnica między numerami grup województw podobnych będzie nie wyższa niż jeden, to obie metody prowadzą do tych samych rezultatów. Wyniki porównań wskazują, że w 28,1\% przypadków województwa charakteryzowały się tym samym numerem grupy, w 53,7\% różnica wynosiła jeden, w 14,6\% jedynie dwa, a w 3,6\% trzy lub cztery. Można zatem uznać, że obie metody są względem siebie komplementarne (tabela 10). 
Tabela 10. Numery grup województw podobnych wyznaczonych według miary podobieństwa (P) i miary asymetrii (C) w latach 1991, 2001 i 2011 oraz trendu $z$ lat 1991-2011

\begin{tabular}{|c|c|c|c|c|c|c|c|c|c|c|c|c|c|c|c|c|c|c|c|c|c|c|c|c|}
\hline \multirow{3}{*}{ Województwo } & \multicolumn{6}{|c|}{ Ogółem } & \multicolumn{6}{|c|}{ Kobiety } & \multicolumn{6}{|c|}{ Mężczyźni } & \multicolumn{6}{|c|}{ Wskaźnik feminizacji } \\
\hline & \multicolumn{2}{|c|}{1991} & \multicolumn{2}{|c|}{2001} & \multicolumn{2}{|c|}{2010} & \multicolumn{2}{|c|}{1991} & \multicolumn{2}{|c|}{2001} & \multicolumn{2}{|c|}{2010} & \multicolumn{2}{|c|}{1991} & \multicolumn{2}{|c|}{2001} & \multicolumn{2}{|c|}{2010} & \multicolumn{2}{|c|}{1991} & \multicolumn{2}{|c|}{2001} & \multicolumn{2}{|c|}{2010} \\
\hline & $\mathrm{C}$ & $P$ & C & $P$ & $C$ & $P$ & $\mathrm{C}$ & $\mathrm{P}$ & C & $P$ & C & P & $\mathrm{C}$ & $\mathrm{P}$ & $C$ & $P$ & $C$ & $P$ & $\mathrm{C}$ & $P$ & C & $P$ & C & P \\
\hline Dolnośląskie & 3 & 3 & 3 & 5 & 2 & 4 & 3 & 3 & 3 & 5 & 2 & 5 & 3 & 3 & 3 & 4 & 2 & 5 & 4 & 4 & 4 & 5 & 3 & 4 \\
\hline Kujawsko-pomo & 3 & 3 & 4 & 3 & 3 & 3 & 3 & 3 & 3 & 3 & 3 & 3 & 3 & 3 & 3 & 3 & 4 & 2 & 4 & 3 & 3 & 3 & 4 & 3 \\
\hline Lubelskie & 4 & 6 & 4 & 5 & 5 & 4 & 4 & 6 & 4 & 5 & 5 & 4 & 4 & 6 & 4 & 5 & 4 & 4 & 5 & 5 & 5 & 6 & 5 & 6 \\
\hline Lubuskie & 2 & 1 & 2 & 1 & 2 & 2 & 2 & 1 & 2 & 1 & 2 & 2 & 2 & 1 & 2 & 1 & 2 & 2 & 3 & 4 & 3 & 5 & 3 & 4 \\
\hline Łódzkie & 5 & 6 & 5 & 6 & 5 & 6 & 5 & 6 & 5 & 6 & 5 & 6 & 5 & 6 & 5 & 6 & 5 & 6 & 6 & 2 & 5 & 3 & 4 & 3 \\
\hline Małopolskie & 4 & 4 & 4 & 3 & 4 & 2 & 4 & 4 & 4 & 3 & 4 & 1 & 4 & 4 & 4 & 3 & 4 & 2 & 4 & 4 & 4 & 4 & 4 & 2 \\
\hline Mazowieckie & 5 & 6 & 5 & 6 & 4 & 4 & 5 & 6 & 5 & 6 & 4 & 4 & 5 & 6 & 5 & 6 & 4 & 5 & 4 & 5 & 4 & 5 & 4 & 4 \\
\hline Opolskie & 4 & 3 & 4 & 4 & 4 & 5 & 4 & 4 & 4 & 4 & 4 & 6 & 4 & 3 & 4 & 4 & 4 & 5 & 4 & 4 & 3 & 4 & 4 & 5 \\
\hline Podkarpackie & 3 & 3 & 3 & 2 & 3 & 1 & 3 & 3 & 3 & 2 & 3 & 4 & 3 & 3 & 3 & 1 & 3 & 1 & 4 & 3 & 4 & 3 & 4 & 2 \\
\hline Podlaskie & 4 & 5 & 4 & 4 & 4 & 4 & 4 & 5 & 4 & 4 & 5 & 2 & 4 & 5 & 4 & 4 & 3 & 3 & 4 & 3 & 4 & 4 & 5 & 4 \\
\hline Pomorskie & 3 & 2 & 3 & 2 & 3 & 2 & 3 & 2 & 3 & 2 & 3 & 6 & 3 & 2 & 3 & 3 & 4 & 2 & 3 & 2 & 2 & 3 & 2 & 3 \\
\hline Śląskie & 4 & 4 & 4 & 5 & 4 & 6 & 4 & 4 & 4 & 4 & 4 & 6 & 4 & 4 & 4 & 5 & 5 & 6 & 3 & 3 & 2 & 3 & 2 & 4 \\
\hline Świętokrzyskie & 4 & 6 & 5 & 6 & 5 & 6 & 4 & 6 & 4 & 6 & 5 & 1 & 4 & 6 & 5 & 6 & 5 & 6 & 5 & 5 & 5 & 4 & 5 & 4 \\
\hline Warmińsko-mazurskie & 2 & 1 & 2 & 1 & 2 & 1 & 2 & 1 & 2 & 1 & 2 & 1 & 2 & 1 & 2 & 1 & 2 & 1 & 3 & 2 & 3 & 2 & 4 & 3 \\
\hline Wielkopolskie & 3 & 3 & 3 & 2 & 3 & 1 & 3 & 3 & 3 & 2 & 3 & 3 & 3 & 2 & 3 & 2 & 3 & 1 & 4 & 3 & 3 & 3 & 3 & 2 \\
\hline Zachodniopomorskie & 2 & 1 & 2 & 2 & 2 & 3 & 2 & 1 & 2 & 2 & 2 & 1 & 3 & 1 & 3 & 2 & 3 & 4 & 2 & 2 & 2 & 2 & 2 & 3 \\
\hline Liczba grup & 3 & 5 & 3 & 5 & 3 & 5 & 3 & 5 & 3 & 5 & 3 & 5 & 3 & 5 & 3 & 5 & 3 & 5 & 5 & 4 & 4 & 5 & 5 & 5 \\
\hline
\end{tabular}

Źródło: Opracowanie własne na podstawie rysunku 1.

Reasumując, analiza porównawcza uzyskanych wyników przy zastosowaniu tych dwóch metod, tj. wskaźnika prawdopodobieństwa struktur oraz miary asymetrii, prowadzi do podobnych wniosków, z tym, że w przypadku pierwszej metody podobieństwo w skupiskach między województwami jest nieco większe niż w przypadku drugiej. Metody te można zatem traktować jako komplementarne, a ich wybór powinien zależeć od przyjętych założeń co do określenia skali podobieństwa między tymi jednostkami przestrzennymi.

\section{Zakończenie}

W ocenie starości demograficznej wykorzystuje się wiele miar, które można podzielić na trzy kategorie. Do pierwszej należą te, które przedstawiają relację między 
liczbą (lub odsetkiem) osób będących w określonym wieku. W drugiej wykorzystuje się informacje o przeciętnym dalszym trwaniu życia lub syntetycznych miarach statystycznych opisujących rozkład liczby ludności według wieku. W trzeciej zaś analizuje się łącznie informacje o poszczególnych grupach wieku. Natomiast zmiany w czasie rozważa się jako relację między punktowymi wartościami przedstawionych wyżej wskaźników starości lub jako iloraz między ich średnim rocznym tempem zmian. Można znaleźć wiele prac poświęconych tym zagadnieniom, ale analizuje się je przede wszystkim w ujęciu ogółem. Brak natomiast takich rozważań w podziale na płeć oraz takich, które porównują wyniki przy zastosowaniu różnych metod. Opracowanie miało na celu uzupełnienie tej luki. Przeprowadzono zatem opis przestrzennego zróżnicowania stopnia zaawansowania starości demograficznej przy wykorzystaniu dwóch metod, tj. podobieństwa struktur i miary asymetrii. Analizy prowadzone były dla lat 1991, 2001 i 2011 według województw, odrębnie dla populacji kobiet i mężczyzn.

Nie wszystkie z postawionych na wstępie hipotez badawczych potwierdzily się. Województwa o podobnym stopniu zaawansowania starości demograficznej nie zawsze tworzyły zwarte przestrzennie obszary (nie zawsze posiadały co najmniej jedną wspólną granicę). Były to raczej skupiska wieloelementowe, rozlokowane w różnych częściach kraju. Syntetyczne miary rozproszenia pokazały zaś, że z czasem struktury te stały się nieco bardziej podobne między województwami oraz że we wszystkich województwach postępuje proces ich upodabniania się do struktury typu regresywnego. We wszystkich województwach odnotowujemy postępujący proces starzenia się ludności, ale brak jest wyraźnego skorelowania między tą przestrzenną dynamiką a jej stanem wyjściowym. Jednakże większość województw położonych we wschodniej części kraju odznaczała się wyższym stopniem zaawansowania starości demograficznej aniżeli te, które znajdowały się w jej części zachodniej. Delimitacja obszarów podobnych różniła się w populacji kobiet w stosunku do populacji mężczyzn, ale z reguły obszar Polski Wschodniej cechował się starszą strukturą wieku. We wszystkich województwach stopień zaawansowania starości demograficznej był wyższy w populacji kobiet niż mężczyzn i dodatkowo z czasem różnice te jeszcze pogłębiły się. Rosły też ich przestrzenne dysproporcje. Przestrzenny obraz nie był stabilny w czasie, ale większość województw, dla których różnica między stopniem zaawansowania starości demograficznej w populacji kobiet była znacznie wyższa aniżeli w populacji mężczyzn, rozlokowanych było przede wszystkim w północnej części kraju oraz w części południowo-wschodniej i centralnej. Natomiast najniższe różnice odnotowaliśmy w części środkowowschodniej. Nie zaobserwowano wyraźnej przestrzennej zależności między wartością wskaźnika feminizacji a jego zmianami w czasie. Jednakże większość województw charakteryzująca 
się niską dynamiką położona była w północno-wschodniej części kraju, a wysoką w centralnej. Oznacza to, że w pierwszym przypadku szybkość upodobniania się struktur wieku kobiet do struktur wieku mężczyzn była wolniejsza niż w drugim przypadku. Analiza porównawcza uzyskanych wyników przy zastosowaniu tych dwóch metod, tj. wskaźnika prawdopodobieństwa struktur oraz miary asymetrii, prowadzi do podobnych wniosków, z tym, że w przypadku pierwszej metody podobieństwo w skupiskach między województwami jest nieco większe niż w przypadku tej drugiej. Metody te można zatem traktować jako komplementarne, a ich wybór powinien zależeć od przyjętych założeń co do określenia skali podobieństwa między tymi jednostkami przestrzennymi.

Wydaje się, że prowadzone rozważania dają podstawową wiedzę w zakresie zmian w strukturze ludności, która jest niezbędna do poprawnego formułowania polityki społeczno-gospodarczej w regionach, zwłaszcza w sferze polityki społecznej oraz ochrony zdrowia. Na szczeblu krajowym odnosi się zaś do planowania wszelkich działań, które mają na celu wyrównywanie szans w rozwoju ekonomicznym tych jednostek przestrzennych.

\section{Population by age and voivodships in Poland, 1991-2011}

The purpose of this article is description of demographic ageing using two methods: resemblance of structures and the measure of asymmetry for the years 1991, 2001 and 2011, for population of women and men separately and comparing results. Voivod ships with population ageing similarly rarely have formed spatially close areas, rather they formed clusters in various parts of the country. With passing time age structures by voivod ship started to resemble regressive type structure, but their dynamics was independent from the structure recorded in 1990. Population of majority of voivod ships located in the Eastern part of the country was older than population of Western voivod ships. Similarly, population of women was older than population of men. The comparative analysis of result leads to similar conclusions.

Keywords: old age, ageing, structure of the population 


\section{La population par âge et par voïvodie en Pologne (1991-2011)}

Cet article décrit le processus de_vieillissement démographique_en s'appuyant sur_deux méthodes: la ressemblance de structures et la mesure de l'asymétrie pour la population des femmes et des hommes, pour les années 1991, 2001 et 2011. Les résultats ont été comparés. Les voïvodies où on a observé un vieillissement semblable de la population se sont rarement formées dans des zones proches; ils ont plutôt formé des grappes dans différentes parties du pays. Au fil du temps les structures d'âge par voïvodie ont commencé à ressembler à une structure de type régressif, mais leur dynamique était indépendante de la structure enregistrée en 1990. La population de la majorité des voïvodies situées dans la partie orientale du pays était plus âgée que la population des voïvodies occidentales. De même, la population des femmes était plus âgée que la population des hommes. L'analyse comparative de ces résultats conduit à des conclusions similaires.

Mots-clés: la vieillesse, le vieillissement, la structure de la population

\section{Пространственная диверсификация возрастной структуры населения Польши в 1991-2011 гг.}

Для оценки демографического старения используются различные показатели. Во многих работах анализируется пространственное изменение этого процесса, относясь только к количеству (или проценту) лиц по возрасту. Целью настоящей статьи является описание этого процесса при использовании двух методов: сходства структур и меры асимметрии за 1991, 2001 и 2011 гг., проведенных отдельно для группы мужчин и женщин, и сравнения достигнутых результатов. Воеводства в подобной стадии демографического старения не всегда образовывали пространственно компактные территории, а чаще всего - скопления в разных частях страны. Со временем, возрастные структуры населения по воеводствам стали более похожи на структуры регрессивного типа, но их динамика не зависела от их структуры 1990 г. В большинстве воеводств восточной части страны процесс демографического старения был болеепродвинутым чем в воеводствах западной части Польши, а популяция женщин была старше мужчин. Сравнительный анализ результатов, полученных при использовании двух методов, приводит 
к аналогичным выводам. Следует заметить, что при первом методе сходство в скоплениях между воеводствами выше чем при втором.

Ключевые слова: старость, старение, структура населения 